\title{
Validation of an in vitro model for predicting rumen and total-tract fiber digestibility in dairy cows fed corn silages with different in vitro neutral detergent fiber digestibilities at 2 levels of dry matter intake
}

\author{
F. Lopes, D. E. Cook, and D. K. Combs ${ }^{1}$ \\ Department of Dairy Science, University of Wisconsin, Madison 53706
}

\begin{abstract}
An in vivo study was performed to validate an in vitro procedure that predicts rate of fiber digestion and totaltract neutral detergent fiber digestibility (TTNDFD). Two corn silages that differed in fiber digestibility were used in this trial. The corn silage with lower fiber digestibility (LFDCS) had the TTNDFD prediction of $36.0 \%$ of total NDF, whereas TTNDFD for the corn silage with higher fiber digestibility (HFDCS) was $44.9 \%$ of total neutral detergent fiber (NDF). Two diets (1 with LFDCS and 1 with HFDCS) were formulated and analyzed using the in vitro assay to predict the TTNDFD and rumen potentially digestible NDF (pdNDF) digestion rate. Similar diets were fed to 8 ruminally cannulated, multiparous, high-producing dairy cows in 2 replicated $4 \times 4$ Latin squares with 21 -d periods. A 2 $\times 2$ factorial arrangement of treatments was used with main effects of intake (restricted to approximately $90 \%$ of ad libitum intake vs. ad libitum) and corn silage of different fiber digestibility. Treatments were restricted and ad libitum LFDCS as well as restricted and ad libitum HFDCS. The input and output values predicted from the in vitro model were compared with in vivo measurements. The pdNDF intake predicted by the in vitro model was similar to pdNDF intake observed in vivo. Also, the pdNDF digestion rate predicted in vitro was similar to what was observed in vivo. The in vitro method predicted TTNDFD of $50.2 \%$ for HFDCS and $42.9 \%$ for LFDCS as a percentage of total NDF in the diets, whereas the in vivo measurements of TTNDFD averaged 50.3 and $48.6 \%$ of total NDF for the HFDCS and LFDCS diets, respectively. The in vitro TTNDFD assay predicted total-tract NDF digestibility of HFDCS diets similar to the digestibility observed in vivo, but for LFDCS diets the assay underestimated the digestibility compared with in vivo. When the in vitro and in vivo measurements were compared without intake effect (ad libitum and restricted) considering only diet
\end{abstract}

Received July 25, 2014.

Accepted October 8, 2014.

${ }^{1}$ Corresponding author: dkcombs@wisc.edu effect of silage fiber digestibility (HFDCS and LFDCS), no differences were observed between methods. These values suggest that our in vitro TTNDFD model could be used to predicted rate of fiber digestion and NDF digestibility for dairy cattle.

Key words: corn, fiber digestibility, rate of digestion, in vitro prediction

\section{INTRODUCTION}

Improving our understanding of fiber digestion mechanisms is essential to better estimate the digestible energy coming from fiber sources and improving animal performance. Fiber digestion occurs primarily in the rumen and is the result of a dynamic process that is affected by the chemical nature of the plant fiber and by the digestion and passage of fiber within the animal's digestive tract. Rate of fiber digestion (kd) and the proportion of NDF that is potentially digestible (pdNDF) vary considerably between and within forage types (Mertens, 2002). Rate of passage of fiber (kp) is primarily affected by level of intake of the animal, and, consequently, fiber digestibility increases with longer retention time of feed in the rumen (Huhtanen et al., 2007). Therefore, ruminal fiber digestion can be described mathematically as proportion of fiber digested $=\operatorname{pdNDF} \times[(\mathrm{kd}) /(\mathrm{kd}+\mathrm{kp})]$, as described by Mertens (2002).

Fiber digestion kinetics can be measured in vivo by the rumen evacuation technique or fill and flux method (Taylor and Allen, 2005; Huhtanen et al., 2007). This method is carried out with ruminally cannulated animals, which allows measurement of the pools of digestible and indigestible fiber that flow from the rumen (Huhtanen et al., 1997).

Despite the accuracy of estimating the rumen kinetic parameters by rumen evacuation technique, this type of measurement is impractical for routine forage analysis. University of Wisconsin researchers developed a model that uses an in vitro NDF fermentation assay to measure the proportion pdNDF and rate of digestion of NDF to predict total-tract digestibility (TTNDFD) for lactating dairy cattle (Combs, 2013). The objective 
of the current study was to compare estimates of totaltract fiber digestibility as predicted by this in vitro TTNDFD model to in vivo measurements in lactating dairy cows fed diets that varied in corn silage fiber digestibility and intake level.

\section{MATERIALS AND METHODS}

\section{In Vitro Rumen and TTNDFD Prediction}

A model has been developed which predicts TTNDFD (Combs, 2013). The in vitro model is based on the concept that fiber digestion is a 2-step process beginning in the rumen followed by fiber digestion in the hindgut. Ruminal digestion of NDF is a time-dependent, competitive process affected by the $\mathrm{kp}$ of pdNDF from the rumen and the amount and kd of pdNDF, similar to the cellulose digestion model described by Waldo et al. (1972). The amount of pdNDF is calculated from the difference of total NDF and indigestible NDF (iNDF; pdNDF $=\mathrm{NDF}-\mathrm{iNDF}$; NRC, 2001). Indigestible $\mathrm{NDF}$ is determined by in vitro incubation of feedstuff in buffered rumen fluid for $240 \mathrm{~h}$ without rumen reinoculation by the in vitro procedure described by Goeser and Combs (2009). The $\mathrm{kd}$ of pdNDF is calculated from NDF residue measurements taken at 24, 30, and $48 \mathrm{~h}$ of in vitro incubation in rumen fluid (Goeser and Combs, 2009) using a first-order kinetics model with an indigestible fraction as described by Mertens (1993), which assumes that the indigestible residue does not disappear and pdNDF residue disappears at a rate that is proportional to its mass at any time. The pdNDF $\mathrm{kp}$ was predicted from a regression model (Krizsan et al., 2010a) for iNDF which is adjusted to account for the selective retention of pdNDF (Lund et al., 2007) determined using the flux/compartment pool method described by Ellis et al. (1994). In the TTNDFD model, the predicted NDF digestibility was indexed to a dairy cow at $630 \mathrm{~kg}$ of BW consuming $23.4 \mathrm{~kg} / \mathrm{d}$ of DM of a diet containing $30 \%$ of NDF. This index sets the $\mathrm{kp}$ of pdNDF at $2.67 \% / \mathrm{h}$. Hindgut digestion of NDF is assumed to be $10 \%$ of total NDF digestion. Total-tract NDF digestibility is expressed as a percentage of total $\mathrm{NDF}$ as $\mathrm{TTNDFD}=100 \times\{\mathrm{pdNDF} \times[\mathrm{kd} /(\mathrm{kd}+$ $\mathrm{kp})]\} / 0.9$.

In December 2011, 2 samples of corn silage were collected from 5 different silo bunks from the inventory of forages from US Dairy Forage Research Center (Prairie du Sac, WI), University of Wisconsin West-Madison, and University of Wisconsin-Arlington research stations. The corn silages were analyzed to predict totaltract NDF digestibility using the in vitro TTNDFD model. The silages chosen for this trial were most different in fiber digestibility. The corn silage (Pioneer
35F37; Pioneer Hi-Bred, Johnston, IA) with lower fiber digestibility (LFDCS) had the TTNDFD prediction of $36.0 \pm 4.6 \%$ of total NDF $( \pm \mathrm{SD})$, and TTNDFD for corn silage (Mycogen F2F622 brown midrib, BMR; Mycogen Seeds, Indianapolis, IN) with higher fiber digestibility (HFDCS) was $44.9 \pm 4.9 \%$ of total NDF. Nutrient composition of the silages is presented in Table 1. Diets were formulated to have similar content of NDF, with approximately $60 \%$ of forage and $40 \%$ of concentrate of the diet DM. Ingredient composition of the experimental diets is provided in Tables 2 and 3. The 2 diets (LFDCS and HFDCS; Table 3) were formulated and analyzed using the in vitro assay to predict the TTNDFD and rumen pdNDF $\mathrm{kd}$ and $\mathrm{kp}$.

\section{In Vivo Trial}

Eight ruminally cannulated, multiparous Holsteins cows, averaging $110 \pm 5 \mathrm{DIM}$ and $671 \pm 12.5 \mathrm{~kg}$ of BW at the beginning of the trial, were randomly assigned to a treatment sequence within a replicated $4 \times 4$ Latin squares. A $2 \times 2$ factorial arrangement of treatments was used with main effects of intake (restricted to approximately $90 \%$ of ad libitum intake vs. ad libitum) and corn silage that differed in fiber digestibility. Treatments were restricted and ad libitum LFDCS as well as restricted and ad libitum HFDCS. Treatments periods were $21 \mathrm{~d}$, consisting of $11 \mathrm{~d}$ for diet adaptation followed by $10 \mathrm{~d}$ for sampling and data collection. Cows were housed in tiestalls at Dairy Cattle Center at University of Wisconsin-Madison. Care and handling of the animals, including ruminal cannulation, were conducted as outlined in the guidelines of the University of Wisconsin institutional animal care and use committee.

Cows were fed twice a day (0900 and $1800 \mathrm{~h}$ ) and amounts of feed offered (adjusted daily according to treatment intake) and orts (only ad libitum treatments) were weighed for each cow daily. Forage samples were collected weekly to adjust for DM. All diet ingredients, TMR, and orts were collected on d 16 to 21 and combined into 1 sample per period and stored at $-20^{\circ} \mathrm{C}$ for further nutrient analysis. Dry matter content of all feeds, TMR, and orts were determined by drying at $60^{\circ} \mathrm{C}$ (forced-air oven) for $48 \mathrm{~h}$. Dried samples were ground to pass a 1-mm screen (Wiley mill; Arthur H. Thomas, Philadelphia, PA) and analyzed for DM, OM (method 942.05; AOAC International, 2006), CP (method 990.03; AOAC International, 2006), ether extract (method 2003.05; AOAC International, 2006), NDF using $\alpha$-amylase and sodium sulfite (Van Soest et al., 1991), starch (Bach Knudsen, 1997; YSI Biochemistry Analyzer, YSI Inc., Yellow Springs, OH), lignin (method 973.18; AOAC International, 2006), and iNDF (Krizsan and Huhtanen, 2013). 
Table 1. Nutrient composition of silages

\begin{tabular}{|c|c|c|c|}
\hline Item & $\mathrm{LFDCS}^{1}$ & $\mathrm{HFDCS}^{1}$ & $\begin{array}{l}\text { Alfalfa } \\
\text { silage }\end{array}$ \\
\hline DM, $\%$ as fed & $35.2 \pm 0.2$ & $30.5 \pm 0.4$ & $41.2 \pm 1.8$ \\
\hline $\mathrm{OM}, \%$ of $\mathrm{DM}$ & $96.6 \pm 0.4$ & $96.7 \pm 0.4$ & $89.3 \pm 0.6$ \\
\hline $\mathrm{CP}, \%$ of $\mathrm{DM}$ & $6.41 \pm 0.1$ & $6.89 \pm 0.2$ & $21.1 \pm 0.2$ \\
\hline Starch, \% of DM & $30.0 \pm 1.0$ & $27.8 \pm 1.0$ & $0.72 \pm 0.1$ \\
\hline Lignin, \% of DM & $2.68 \pm 0.1$ & $2.74 \pm 0.2$ & $8.30 \pm 0.2$ \\
\hline Ether extract, $\%$ of DM & $3.22 \pm 0.1$ & $3.06 \pm 0.2$ & $2.88 \pm 0.0$ \\
\hline Ash, $\%$ of DM & $3.10 \pm 0.3$ & $3.66 \pm 0.1$ & $11.1 \pm 0.6$ \\
\hline NDF, $\%$ of DM & $34.4 \pm 0.8$ & $38.4 \pm 0.3$ & $34.7 \pm 0.5$ \\
\hline iNDF, ${ }^{2} \%$ of NDF & $35.5 \pm 0.2$ & $25.7 \pm 1.2$ & $47.8 \pm 0.9$ \\
\hline pdNDF kd, ${ }^{3} \% / \mathrm{h}$ & $2.69 \pm 0.1$ & $3.31 \pm 0.1$ & $6.11 \pm 0.2$ \\
\hline TTNDFD, ${ }^{4} \%$ of total NDF & $36.0 \pm 4.6^{\mathrm{b}}$ & $44.9 \pm 4.9^{\mathrm{a}}$ & $42.2 \pm 2.3^{\text {ah }}$ \\
\hline
\end{tabular}

${ }^{a, b}$ Means in the same row with different superscripts differ $(P<0.05)$.

${ }^{1}$ LFDCS $=$ low-fiber digestibility corn silage; HFDCS $=$ high-fiber digestibility corn silage.

${ }^{2}$ iNDF $=$ indigestible NDF determined by in situ incubation for $288 \mathrm{~h}$.

${ }^{3}$ pdNDF $\mathrm{kd}=$ potential digestible NDF fraction digestion rate calculate from TTNDFD model.

${ }^{4}$ TTNDFD $=$ predicted total-tract NDF digestibility using in vitro TTNDFD model.

Cows were milked twice daily and milk yield was recorded at each milking. Milk samples from morning and evening milkings were collected on d 12 to 15 of each period and analyzed for fat, true protein, lactose, and MUN concentrations and SCC by infrared analysis (AgSource Milk Analysis Laboratory, Menomonie, WI) using a Foss FT6000 (Foss Electric, Hillerød, Denmark) with average daily yields of fat and protein calculated from these data for each period. Yield of FCM and ECM were calculated according to NRC (2001) equations.

\section{Omasal and Rumen Sampling}

Spot samples of omasal digesta leaving the rumen were obtained from the 8 ruminally cannulated cows using the omasal sampling technique described by Huhtanen et al. (1997), Ahvenjärvi et al. (2000), and Reynal and Broderick (2005). The omasal digesta markers used were iNDF (Huhtanen et al., 1994) for the large particle phase (LP), Lanthanum (La) (Kendall et al., 2009) for the small particle phase (SP), and CoEDTA (Co) (Udén et al., 1980) for the fluid phase (FP). Gelatin capsules (1.5 oz., Tropac Inc., Airfield, NJ) containing $1 \mathrm{~g}$ of La and $0.75 \mathrm{~g}$ of Co and approximately $2 \mathrm{~g}$ of ground spelt hulls were dosed through the ruminal cannula at $0600,1200,1800$, and $0000 \mathrm{~h}$ (total of $4 \mathrm{~g}$ of La and $3 \mathrm{~g}$ of Co per day) from 12 to $18 \mathrm{~d}$ with a $3 \times$ priming dose on $\mathrm{d} 12$. Omasal sampling began approximately $96 \mathrm{~h}$ after the first marker dose; samples were then taken 4 times daily at 2 -h intervals over 3 consecutive days to represent the 24 -h feeding cycle: 0000, 0200, 0400, 0600 (d 16), 0800, 1000, 1200, 1400 (d 17), and 1600, 1800, 2000, and $2200 \mathrm{~h}$ (d 18). Before each sampling, it was necessary to confirm the location of the sampling omasal tube, and occasionally it had to be repositioned in the omasal canal. At each sampling time, 200-mL subsamples were pooled and stored at $-20^{\circ} \mathrm{C}$ over all $3 \mathrm{~d}$ to obtain a single 2.4 -L composite from each cow in each period for later separation into the 3 omasal phases.

The pooled omasal composites were thawed at room temperature, separated into the 3 omasal phases (LP, $\mathrm{SP}$, and FP) as described by Reynal and Broderick (2005), and stored at $-20^{\circ} \mathrm{C}$ until freeze-dried at Anteco Pharma (Lodi, WI). After freeze-drying, LP samples were ground through a 1-mm screen (Wiley mill; Arthur H. Thomas), SP and FP samples were ground using a coffee grinder, then all were analyzed for markers. Concentration of Co, La, and iNDF in LP and SP and Co and La in FP were determined using the methods detailed previously by Reynal and Broderick (2005)

Table 2. Ingredient and nutrient composition of diets

\begin{tabular}{lcc}
\hline Item & LFDCS $^{1}$ & HFDCS $^{1}$ \\
\hline $\begin{array}{l}\text { Ingredient, \% of DM } \\
\text { LFDCS }\end{array}$ & 47.1 & - \\
HFDCS & - & 47.4 \\
Alfalfa silage & 17.1 & 12.3 \\
$\quad$ Concentrate mix & & 40.3 \\
Nutrient composition & & \\
DM, \% of as fed & $53.1 \pm 0.3$ & $52.8 \pm 0.2$ \\
OM, \% of DM & $93.3 \pm 0.2$ & $92.8 \pm 0.1$ \\
CP, \% of DM & $16.2 \pm 0.1$ & $16.4 \pm 0.1$ \\
Starch, \% of DM & $21.7 \pm 0.5$ & $21.4 \pm 0.5$ \\
NFC, \% of DM & $46.4 \pm 0.4$ & $46.0 \pm 0.2$ \\
Lignin, \% of DM & $2.94 \pm 0.1$ & $2.62 \pm 0.1$ \\
Ether extract, \% of DM & $3.43 \pm 0.1$ & $3.01 \pm 0.1$ \\
Ash, \% of DM & $7.15 \pm 0.1$ & $7.35 \pm 0.1$ \\
\hline
\end{tabular}

${ }^{1}$ LFDCS $=$ low-fiber digestibility corn silage; HFDCS $=$ high-fiber digestibility corn silage.

${ }^{2}$ Concentrate mix contained $17.2 \%$ ground corn grain, $12.51 \%$ soybean meal $(47 \%), 7.52 \%$ excel soy, $0.56 \%$ calcium carbonate, $0.68 \%$ sodium bicarbonate, $0.43 \%$ potassium carbonate, $1.68 \%$ trace mineral and salt $0.22 \%$ premix and vitamin premix ADE. 
Table 3. Fiber components of diets as predicted from in vitro analysis

\begin{tabular}{lcc}
\hline Nutrient composition & LFDCS $^{1}$ & HFDCS $^{1}$ \\
\hline NDF, \% of DM & $26.8 \pm 0.4$ & $27.3 \pm 0.2$ \\
iNDF, ${ }^{2} \%$ of NDF & $31.3 \pm 0.1$ & $25.0 \pm 0.7$ \\
Forage NDF, \% of DM & $22.4 \pm 0.3$ & $20.7 \pm 0.1$ \\
Ruminal pdNDF kd, ${ }^{3} / \mathrm{h}$ & $3.50 \pm 0.4$ & $4.18 \pm 0.2$ \\
TTNDFD, ${ }^{4} \%$ of NDF & $42.9 \pm 1.9$ & $50.2 \pm 1.2$ \\
\hline
\end{tabular}

${ }^{1}$ LFDCS $=$ low-fiber digestibility corn silage; HFDCS $=$ high-fiber digestibility corn silage.

${ }^{2} \mathrm{iNDF}=$ indigestible NDF determined by in situ incubation for $288 \mathrm{~h}$. ${ }^{3} \mathrm{pdNDF}=$ potential digestible NDF fraction; $\mathrm{kd}=$ digestion rate calculated from in vitro assay.

${ }^{4}$ TTNDFD $=$ Predicted total-tract NDF digestibility using TTNDFD test.

using inductively coupled plasma optical emission spectrometry at a commercial laboratory (Analabs, Fulton, IL) using a Varian Vista-MPX (Agilent Technologies Inc., Santa Clara, CA). Marker concentrations were used to physically recombine DM from the freeze-dried FP, SP, and LP in the correct proportions to reconstitute the omasal apparent digesta flowing out of the rumen using the triple-marker method of France and Siddons (1986). Concentrations of Co, La, and iNDF were distinctly greater in FP, SP, and LP, respectively, thus allowing for successful application of the triplemarker method.

Ruminal fluid was collected from 3 spots in the rumen using a rumen probe at the same time of omasal sampling. A portable pH meter (Accumet AP61, Fisher Scientific, Pittsburgh, PA) was used immediately on the collected ruminal fluid to determine $\mathrm{pH}$. Two 1-mL aliquots of rumen fluid were added to microcentrifuge tubes containing $0.02 \mathrm{~mL}$ of $50 \% \mathrm{H}_{2} \mathrm{SO}_{4}$ acid and frozen until analysis for VFA. Rumen VFA concentrations were measured by gas liquid chromatography (Supelco, 1998). Concentrations of individual VFA were measured on a Perkin Elmer Clarus 500 (Norwalk, CT) using a 4\% Carbowax $20 M$ on 80/120 mesh Carbopack-B-DA, $1.8 \times 2 \mathrm{~mm}$ column (Supelco Inc., Bellefonte, PA). Two 1-mL aliquots of rumen fluid were acidified with $0.2 \mathrm{~mL}$ of $50 \%$ trichloroacetic acid solution and frozen until analysis for ammonia concentration as described by Bal et al. (2000).

Ruminal contents were evacuated manually through

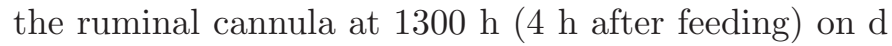
20 and at $0800 \mathrm{~h}(1 \mathrm{~h}$ before feeding) on $\mathrm{d} 21$ of each period. Body weights were measured immediately after rumen evacuation. Total ruminal content mass and volume were determined; $1-\mathrm{kg}$ subsamples of ruminal digesta were collected for further nutrient analysis and evacuated digesta were placed back in the rumen. $\mathrm{Ru}-$ minal pool sizes $(\mathrm{kg})$ of OM, NDF, iNDF, pdNDF, and starch were determined by multiplying the concentration of each component by the ruminal digesta DM mass $(\mathrm{kg})$. Turnover rate, passage rate from the rumen, and ruminal digestion rate of each component $(\% / \mathrm{h})$ were calculated using the following equations:

\section{Ruminal turnover rate $(\% / \mathrm{h})=100$ \\ $\times[($ intake of nutrient/ruminal pool of nutrient)/24];}

Ruminal passage rate $(\% / \mathrm{h})=100 \times[($ omasal

nutrient flow/ruminal pool size of nutrient)/24]; and

Ruminal digestion rate $(\% / \mathrm{h})=$ ruminal turnover rate $(\% / \mathrm{h})$ - ruminal passage rate $(\% / \mathrm{h})$.

Apparent total-tract digestibilities of DM, OM, NDF, pdNDF, and starch were determined using iNDF as an internal marker. Six fecal grab samples were collected from each cow at 0000, 0600 (d 16), 0800, 1400 (d 17), and 1600 and $2200 \mathrm{~h}$ to represent the 24 -h feeding cycle. Fecal samples were composited by period and analyzed for DM, OM, NDF, starch, lignin, and iNDF.

\section{Statistical Analysis}

In vivo data were analyzed using the mixed procedures of SAS (SAS Institute, 2009) for a replicated $4 \times$ 4 Latin square design according to the following model:

$\mathrm{Y}_{\mathrm{ijkwv}}=\mu+\mathrm{L}_{\mathrm{i}}+\mathrm{P}_{\mathrm{j}}+\mathrm{C}_{\mathrm{k}(\mathrm{i})}+\mathrm{F}_{\mathrm{w}}+\mathrm{I}_{\mathrm{v}}+\mathrm{FI}_{\mathrm{wv}}+\mathrm{e}_{\mathrm{ijkwv}}$,

where $\mathrm{Y}_{\mathrm{ijkwv}}=$ dependent variable, $\mu=$ overall mean, $\mathrm{L}_{\mathrm{i}}$ $=$ square effect ( $\mathrm{i}=1$ to 2 ), $\mathrm{P}_{\mathrm{j}}=$ fixed effect of period $(\mathrm{j}=1$ to 4$), \mathrm{C}_{\mathrm{k}(\mathrm{i})}=$ random effect of cow $\mathrm{k}$ (within square i), $\mathrm{F}_{\mathrm{w}}=$ fixed effect of forage source (LFDCS and HFDCS; $\mathrm{w}=1$ to 2$), \mathrm{I}_{\mathrm{v}}=$ fixed effect of intake (restricted and ad libitum; $\mathrm{v}=1$ to 2 ), $\mathrm{FI}_{\mathrm{wv}}=$ interaction between forage source $(\mathrm{w})$ and intake $(\mathrm{v})$, and $\mathrm{e}_{\mathrm{ijkwv}}$ $=$ residual error. Significance was declared at $P \leq 0.05$ and trends at $0.05<P \leq 0.10$. All reported values are least squares means, which were separated using the PDIFF test in SAS. Orthogonal contrasts were used to determine main effect of forage source, main effect of intake, and the interaction of forage source and intake.

The proportion of pdNDF and rates of digestion and passage of pdNDF predicted from the in vitro model and measured in the in vivo study were compared. The comparison was made by modifying the statistical model described previously and replacing the fixed effect of intake by the fixed effect of method $(1=$ in vivo and $2=$ in vitro). Random effect was unit (square), where unit is flask $=$ in vitro and cow $=$ in vivo. Square effect was 1 to 2 for in vivo, and 1 for in vitro. Significance 
was declared at $P \leq 0.05$. All reported values are least squares means, which were separated using the PDIFF test in SAS. Orthogonal contrasts were used to determine main effect of method. Degrees of freedom were calculated using the Kenward-Roger option.

Ruminal $\mathrm{pH}, \mathrm{VFA}$, and $\mathrm{NH}_{3}$ values were analyzed using repeated measures over time:

$$
\begin{gathered}
\mathrm{Y}_{\mathrm{ijkwv}}=\mu+\mathrm{L}_{\mathrm{i}}+\mathrm{P}_{\mathrm{j}}+\mathrm{c}_{\mathrm{k}(\mathrm{i})}+\mathrm{F}_{\mathrm{w}}+\mathrm{I}_{\mathrm{v}}+\mathrm{FI}_{\mathrm{wv}} \\
+\mathrm{e} 1_{\mathrm{ijkwv}}+\mathrm{H}_{\mathrm{m}}+\mathrm{HFI}_{\mathrm{mwv}}+\mathrm{e} 2_{\mathrm{ijkwvm}},
\end{gathered}
$$

where $\mathrm{Y}_{\mathrm{ijkwv}}=$ dependent variable, $\mu=$ overall mean, $\mathrm{L}_{\mathrm{i}}=$ square effect ( $\mathrm{i}=1$ to 2$), \mathrm{P}_{\mathrm{j}}=$ fixed effect of period $(\mathrm{j}=1$ to 4$), \mathrm{C}_{\mathrm{k}(\mathrm{i})}=$ random effect of cow $\mathrm{k}$ (within square $\mathrm{i}$ ), $\mathrm{F}_{\mathrm{w}}=$ fixed effect of forage source (LFDCS and HFDCS; $\mathrm{w}=1$ to 2 ), $\mathrm{I}_{\mathrm{v}}=$ fixed effect of intake (restricted and ad libitum; $\mathrm{v}=1$ to 2 ), $\mathrm{FI}_{\mathrm{wv}}=$ interaction between forage source (w) and intake (v), $E 1_{\mathrm{ijkwv}}=$ residual error, $\mathrm{H}_{\mathrm{m}}=$ effect of hours analyzed as repeated measurements, $\mathrm{HFI}_{\mathrm{mwv}}=$ interaction between hour $(\mathrm{m})$, forage source $(\mathrm{w})$, and intake $(\mathrm{v})$, and $\mathrm{E} 2_{\mathrm{ijkwvm}}=$ is the subplot error. The spatial covariance structure, $\mathrm{SP}(\mathrm{POW})$, was used for estimating covariances, and the subject of the repeated measurements was defined as cow(square $x$ period $\times$ source of forage $\times$ intake). Degrees of freedom were calculated using the Kenward-Roger option. All terms were considered fixed except $c_{k(i)}$, e $1_{i j k w v}$, and $e 2_{i j k w v m}$, which were considered random. Interactions between treatments were declared significant at $P<0.05$.

\section{RESULTS AND DISCUSSION}

\section{Forage and Diet Composition}

Chemical composition of forages is shown in Table 1. Crude protein content of LFDCS and HFDCS were similar. Neutral detergent fiber and lignin contents of the forages also were typical of high-quality forages. The HFDCS silage had a slightly higher concentration of NDF (38.4\%) relative to LFDCS and alfalfa silages (34.4 and $34.7 \%$, respectively). Lignin concentration was similar among corn silages, although iNDF as percentage of total NDF for LFDCS was greater than for HFDCS (35.5 and 25.7\%, respectively). Starch concentration was higher for LFDCS (30.0\%) relative to HFDCS (27.8\%) silage. Brown midrib corn silages have been reported to have lower levels of starch compared with conventional hybrids (Bal et al., 2000; Ballard et al., 2001; Kung et al., 2008).

Ingredients and chemical composition of forages and diets used for in vitro and in vivo studies are shown in Tables 2 and 3. Dry matter, CP, and starch contents were similar for both diets, averaging 53.0, 16.3, and
$21.5 \%$, respectively. Diets were similar in NDF. The iNDF as percentage of total NDF content was higher $(31.3 \%)$ for diets with LFDCS than diets with HFDCS (25.0\%). Oba and Allen (2000a) suggested that the improvement in fiber digestibility with BMR lines is largely due to the reduction in the proportion of indigestible fiber.

\section{In Vitro Fiber Digestion Prediction}

The in vitro assay was used to predict the pdNDF kd and TTNDFD of silages and treatment diets (Tables 1 and 3). The in vitro model predicted that the HFDCS was 9 units higher in TTNDFD compared with LFDCS. The in vitro model would suggest that fiber digestibility was higher for HFDCS because of a smaller fraction of iNDF and a faster rate of digestion of pdNDF (Table 1). Rumen pdNDF kd predicted for forages was $2.69 \% / \mathrm{h}$ for LFDCS and $3.31 \% / \mathrm{h}$ for HFDCS, a fixed pdNDF $\mathrm{kp}$ of $2.67 \% / \mathrm{h}$ was used to calculate the digestion rate as described in Materials and Methods (Volden, 2011). These values are similar to values reported in feed tables of the NorFor (2011) feed evaluation system, with NDF digestion $(2.87 \pm 0.59 \% / \mathrm{h})$ for a range of corn silages (approximately with $40.1 \pm 6.0 \%$ of NDF) determined using in situ incubation time of $2,4,8$, 16, 24, 48, and $96 \mathrm{~h}$. The values reported in our study were also similar to values reported by Colombini et al. (2012), who compared predicted pdNDF kd values for corn silages using in situ (NRC, 2001) and in vitro (Ankom Daisy ${ }^{\mathrm{II}}$, Ankom Technology, Macedon, NY) methods, and reported similar digestion rates (2.1 and $2.6 \% / \mathrm{h}$ for in situ and in vitro, respectively) for pdNDF observed in the present study.

Total-tract NDF digestion and ruminal pdNDF kd of diets were predicted using the in vitro assay (Table 2). Diets containing HFDCS were approximately 7 units higher in TTNDFD than LFDCS; these predictions are based on the assumption of a dairy cow consuming 23.4 $\mathrm{kg} / \mathrm{d}$ of DMI, and approximately $630 \mathrm{~kg}$ of BW. In addition, predicted pdNDF kd for LFDCS and HFDCS diets were 3.50 and $4.18 \% / \mathrm{h}$, respectively.

\section{DMI, Milk Yield, and Milk Components}

Dry matter intake, milk production, and composition are shown in Table 4 . Cows on the restricted diets had lower $(P<0.05)$ DMI than ad libitum than was expected; however, DMI did not differ due to corn silage nor was the interaction corn silage by intake significant. Brown midrib silages have been shown to increase DMI in some studies (Eastridge, 1999; Oba and Allen, 2000a; Tine et al., 2001), but not in other studies (Weiss and Wyatt, 2006; Barlow et al., 2012). 
IN VITRO DIGESTIBILITY MODEL VALIDATION

Table 4. Effect of corn silage type and intake level on feed intake, milk production, milk components, and BW change

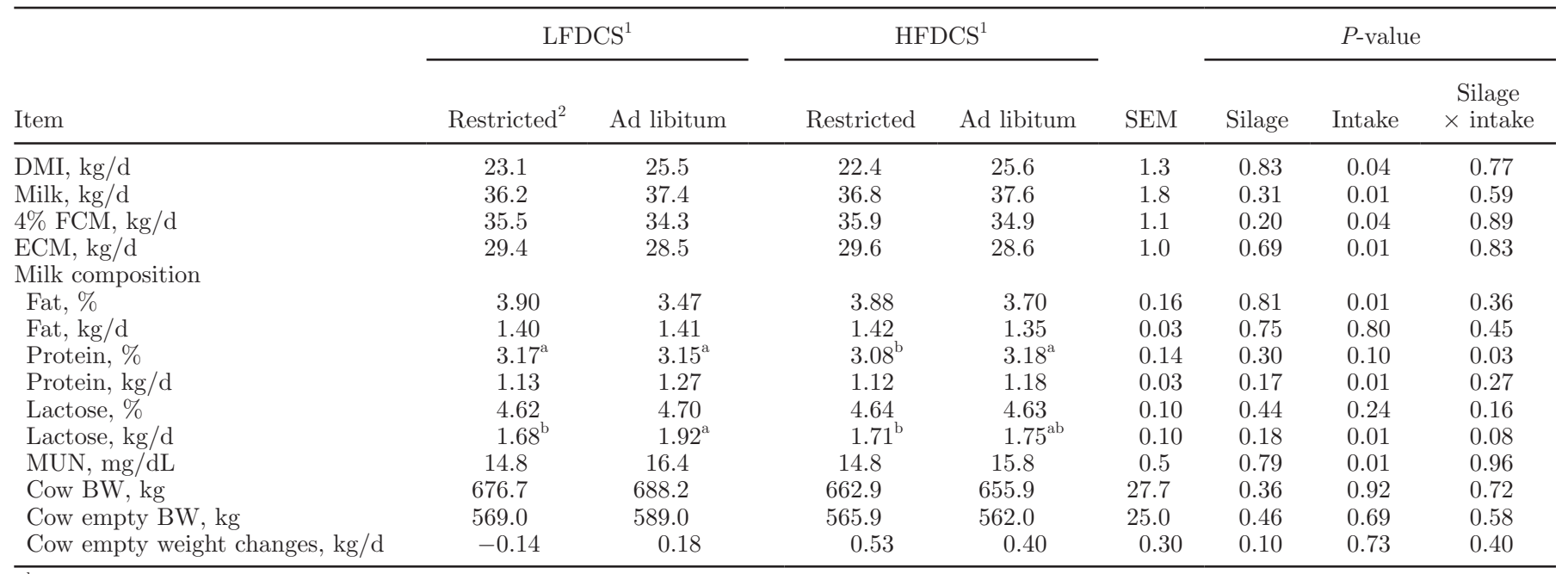

${ }^{\mathrm{a}, \mathrm{b}}$ Means in the same row with different superscripts differ for silage $\times$ intake interaction $(P<0.05)$.

${ }^{1}$ LFDCS $=$ low-fiber digestibility corn silage; HFDCS $=$ high-fiber digestibility corn silage.

${ }^{2}$ DMI restricted to $90 \%$ of ad libitum DMI.

Milk yield was approximately $1 \mathrm{~kg} / \mathrm{d}$ greater for cows fed ad libitum than restricted intake diets; however, no differences were observed due to corn silage type. The interaction corn silage by intake also was not significant. Other studies have reported that milk production was increased by feeding BMR compared with non-BMR hybrids (Oba and Allen, 2000a; Ebling and Kung, 2004; Gehman et al., 2008). Others suggested that increases in milk production $(\mathrm{kg} / \mathrm{d})$ when BMR was fed in trials with high-producing cows, but no difference was observed in cows producing moderate amounts of milk $(\sim 35 \mathrm{~kg} / \mathrm{d}$; Tine et al., 2001; Taylor and Allen, 2005; Weiss and Wyatt, 2006; Kung et al., 2008). Milk fat percentage and $4 \% \mathrm{FCM}$ produced did not differ due to source of corn silage (Table 4). Cows fed restricted LFDCS and HFDCS diets actually produced about 1 $\mathrm{kg} / \mathrm{d}$ more $4 \%$ FCM compared with cows fed ad libitum diets. When cows were fed either diet at $90 \%$ of ad libitum intake, milk fat percentage increased, which may have been the result of a moderate mobilization of body reserves. Production of milk protein, lactose, and MUN concentrations was higher for ad libitum diets, but no difference in these parameters was observed due to corn silage source (Table 4).

Body weight and BW changes were similar among treatments (Table 4); however, cows fed restricted LFDCS tended $(P=0.10)$ to lose weight. This loss in BW could be due to the increase in $4 \% \mathrm{FCM}$ and milk fat percent on the restricted-LFDCS diet due to fat mobilization; however, no loss in BW was observed for the restricted HFDCS diet. Previous studies have reported greater BW gain in lactating cows fed BMR, which was related to the increase in DMI. Tine et al.
(2001) calculated an extra intake of $8.2 \mathrm{Mcal} / \mathrm{d}$ of ME by midlactation cows fed BMR. Block et al. (1981) reported that a small increase in ruminal propionate and the lower ruminal acetate-to-propionate ratio observed in cows fed BMR diets may favor partitioning of energy to BW gain.

\section{Ruminal Fermentation}

The daily ruminal $\mathrm{pH}$ was unaffected by silage type, but $\mathrm{pH}$ was higher for restricted diets (Table 5). A small decrease in ruminal $\mathrm{pH}$ with feeding of BMR compared with conventional corn silage has previously been reported (Greenfield et al., 2001). Presumably, $\mathrm{BMR}$ resulted in increased ruminal digestibility of $\mathrm{OM}$, which led to a higher concentration of VFA (Greenfield et al., 2001). However, in this trial, ruminal digestibility of OM and total VFA were unaffected by corn silage source (as discussed herein). The ruminal $\mathrm{pH}$ was measured every $2 \mathrm{~h}$ during a 24 -h period and cows were fed at 0800 and $1800 \mathrm{~h}$. Significant interactions (time $\times$ silage $\times$ intake; $P<0.05)$ were observed at $4,6,8$, and $22 \mathrm{~h}$ (Figure 1). A higher $\mathrm{pH}$ was observed in the restricted intake. Ruminal $\mathrm{pH}$ among treatments did not go lower than 5.8, which suggested that the cows did not show signs of acidosis (Mouriño et al., 2001).

The proportions of acetate, propionate, and valerate, expressed as a percentage of total VFA, were similar among treatments (Table 5). A silage effect was observed for butyrate, isobutyrate, 2-methylbutyrate, and isovalerate with higher concentration for LFDCS than HFDCS. Greenfield et al. (2001) and Qui et al. (2003) reported a decrease in acetate and acetate-to- 


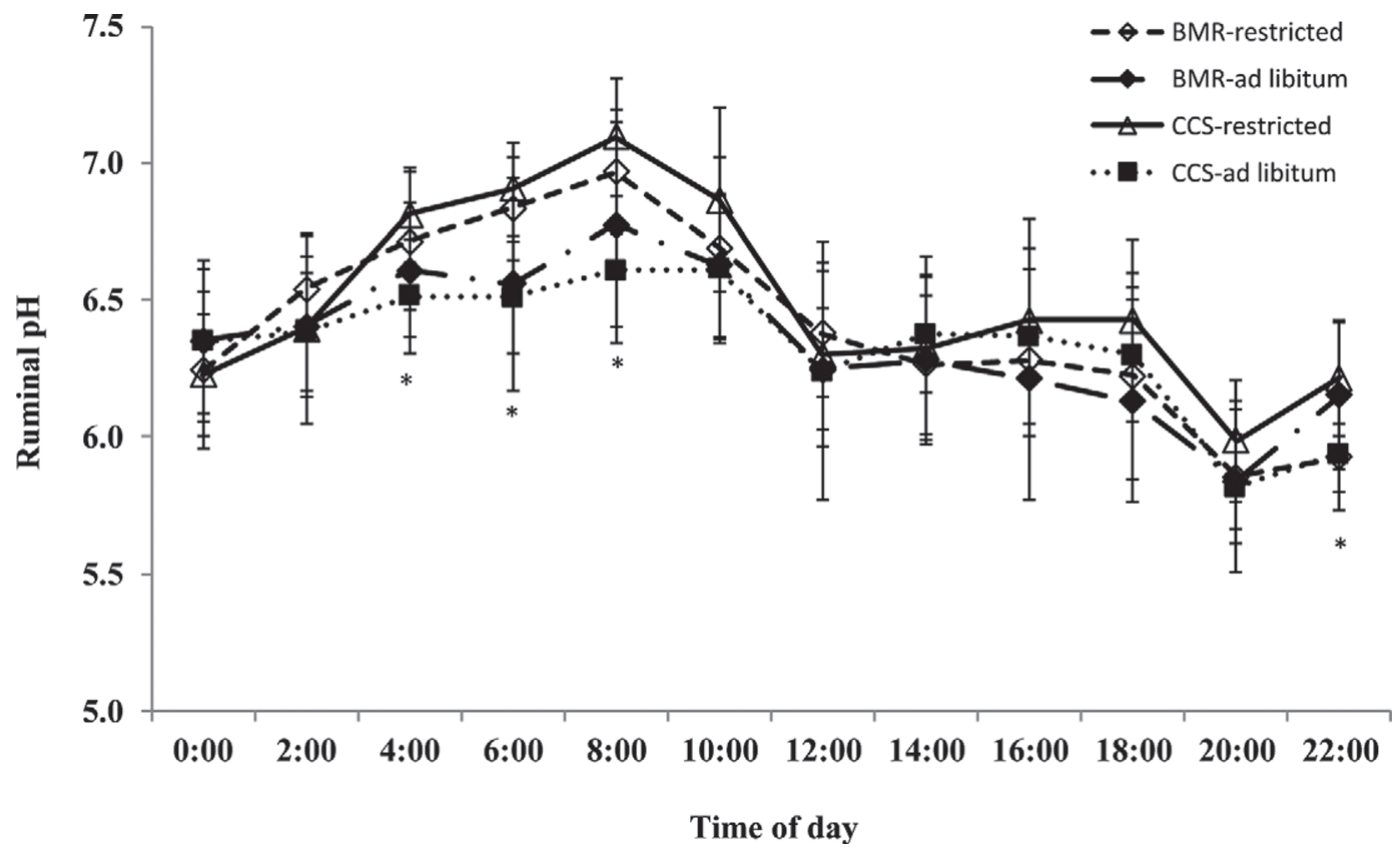

Figure 1. Effects of corn silage type (BMR = brown midrib corn with higher fiber digestibility; CCS = corn silage with lower fiber digestibility) and intake level (restricted or ad libitum) on ruminal $\mathrm{pH}$ (means \pm SED) after feeding. Cows were fed at 0800 and $1800 \mathrm{~h}$. A significant time $\times$ silage $\times$ intake level $(P<0.05)$ was observed and differences among treatments at each sampling time are indicated in the figure by an asterisk $(*)$ at $4,6,8$, and $22 \mathrm{~h}$.

propionate ratio, and an increase in propionate concentration when feeding diets with BMR compared with conventional corn silage. No difference was observed for acetate concentration when HFDCS and LFDCS were compared; however, a tendency $(P=0.06)$ for greater propionate for cows fed HFDCS ad libitum and consequently a decrease in acetate-to-propionate ratio was observed.

\section{In Vivo Ruminal Digestion Kinetics and Pool Size}

Ruminal pool size of DM, OM, NDF, and starch were similar among treatments (Table 6). Indigestible NDF and pdNDF pool sizes were affected by corn silage source, with LFDCS having a higher $(P<0.01)$ content of iNDF fraction than diets with HFDCS. Consequently, HFDCS treatments had a greater $(P<0.01)$ amount

Table 5. Effect of corn silage type and intake level on ruminal fermentation in lactating dairy cows

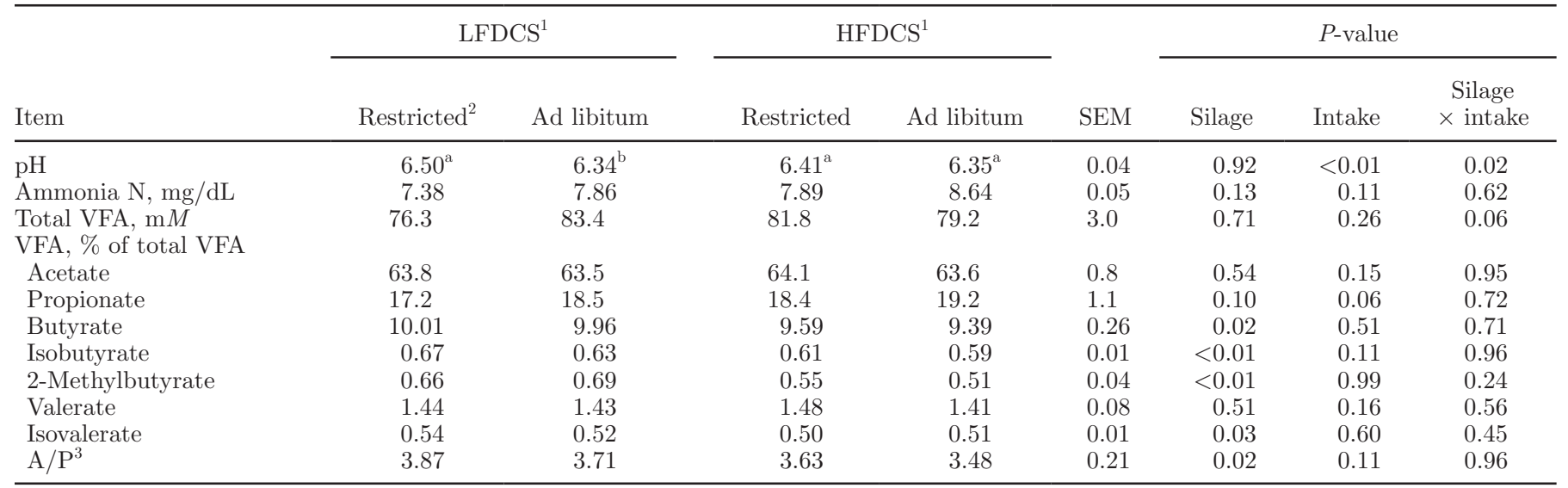

${ }_{\mathrm{a}, \mathrm{b}}$ Means in the same row with different superscripts differ for silage $\times$ intake interaction $(P<0.05)$.

${ }^{1}$ LFDCS $=$ low-fiber digestibility corn silage; HFDCS $=$ high-fiber digestibility corn silage.

${ }^{2} \mathrm{DMI}$ restricted to $90 \%$ of ad libitum DMI.

${ }^{3}$ Acetate-to-propionate ratio. 
of pdNDF fraction in the rumen pool compared with LFDCS diets (Table 6). These differences in pool size of iNDF and pdNDF for HFDCS compared with LFDCS diets were expected, as the HFDCS had approximately $10 \%$ units less iNDF than the LFDCS. Oba and Allen (2000b) found that ruminal pool size of the iNDF and pdNDF fractions were not different between BMR and isogenic corn control diets. The ruminal pool size of nutrients reported by Oba and Allen (2000b) were comparable to the values obtained in our experiment, with the exception of a lower ruminal pool size of starch observed in the current experiment.

The ruminal turnover rate of DM, OM, NDF, and starch were similar among treatments (Table 6). Indigestible NDF turnover rate tended $(P=0.08)$ to be faster in HFDCS than LFDCS diets. The opposite was observed for pdNDF, where the turnover rate tended $(P=0.07)$ to be higher in LFDCS than HFDCS diets. Oba and Allen (2000b) also showed a higher turnover rate for iNDF fraction for BMR than conventional corn silage; Taylor and Allen (2005) reported that rumen turnover of iNDF and pdNDF were similar in diets containing BMR versus isogenic conventional corn silage.
Ruminal digestion rates (Table 6) of DM, OM, and NDF were similar among treatments, with overall means of for LFDCS diets 1.90, 3.84, and $1.73 \% / \mathrm{h}$, respectively, and $2.13,4.10,1.52 \% / \mathrm{h}$ for HFDCS diets, respectively. The digestion rate of pdNDF was not affected by intake level, but it tended $(P=0.09)$ to be faster in LFDCS than HFDCS diets (Table 6). Oba and Allen (2000b) also showed a higher rate of pdNDF digestion for conventional corn silage $(2.29 \% / \mathrm{h})$ compared with BMR $(2.08 \% / h)$ for diets with similar levels of NDF presented in our trial. Taylor and Allen (2005) also reported the same patterns when conventional and BMR diets were compared.

Ruminal passage rate of DM, OM, NDF, pdNDF, and iNDF were similar among corn silage sources and intake level (Table 6). A faster passage rate for iNDF (averaging $3.28 \% / \mathrm{h}$ among treatments) compared with pdNDF (averaging $2.75 \% / \mathrm{h}$ ) was observed in our trial. Taylor and Allen (2005) observed a similar relationship for iNDF kp $(3.27 \% / \mathrm{h})$ and pdNDF kp $(2.55 \% / \mathrm{h})$. Lund et al. (2007) reported that pdNDF fraction is selectively retained in the rumen and consequently the $\mathrm{kp}$ for pdNDF is slower than $\mathrm{kp}$ for iNDF. Krizsan

Table 6. Effect of corn silage type and intake level on rumen digesta mass and volume, rumen fiber and nutrient pools and digestion kinetics

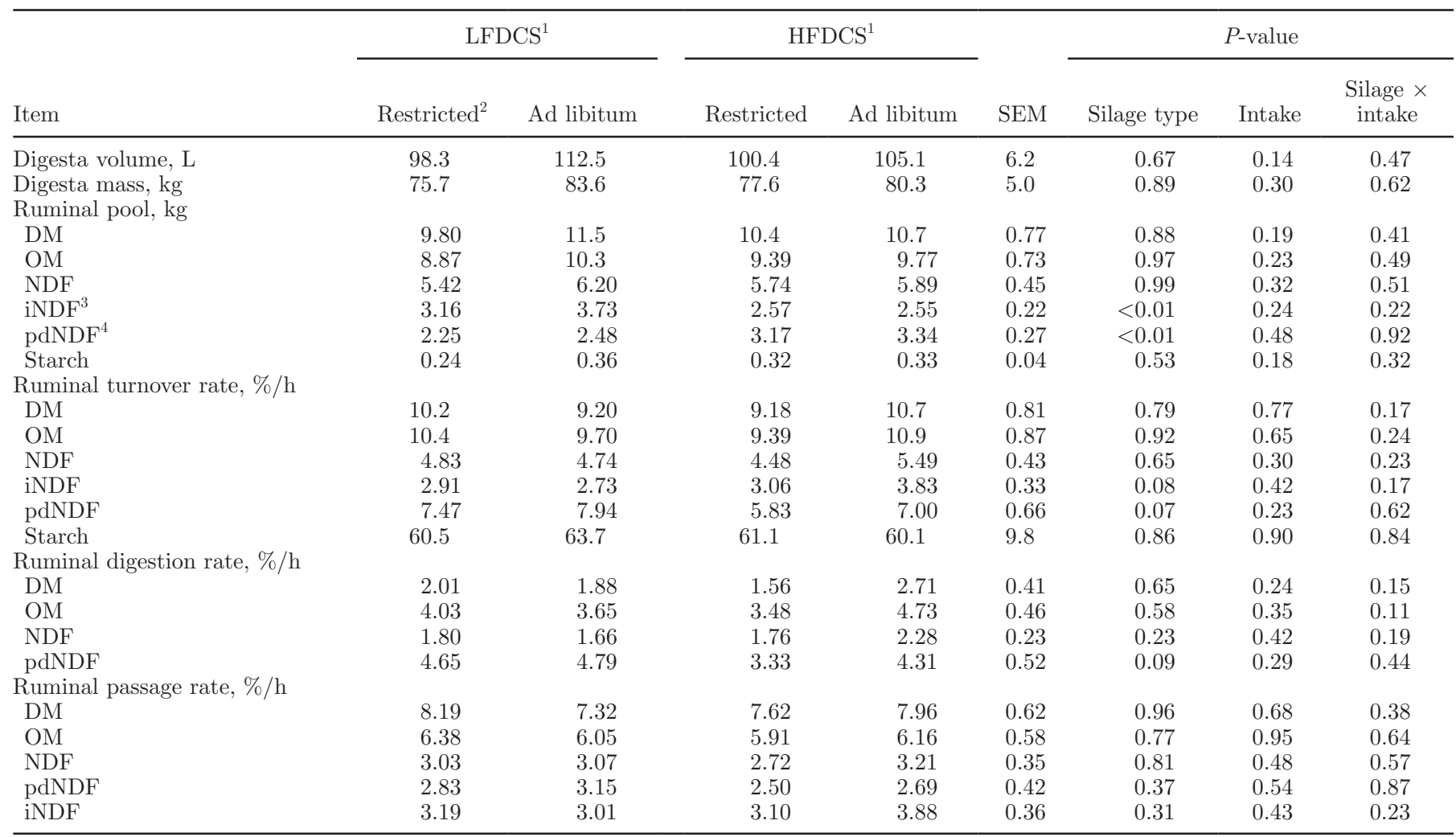

${ }^{1}$ LFDCS $=$ low-fiber digestibility corn silage; HFDCS = high-fiber digestibility corn silage.

${ }^{2} \mathrm{DMI}$ restricted to $90 \%$ of ad libitum DMI.

${ }^{3} \mathrm{iNDF}=$ indigestible NDF determined by in situ incubation for $288 \mathrm{~h}$.

${ }^{4} \mathrm{pdNDF}=$ potential digestible NDF fraction. 
Table 7. Effects of corn silage type and intake level on digestion of DM, OM, and starch

\begin{tabular}{|c|c|c|c|c|c|c|c|c|}
\hline Item & \multicolumn{2}{|c|}{ LFDCS $^{1}$} & \multicolumn{2}{|c|}{$\mathrm{HFDCS}^{1}$} & SEM & \multicolumn{3}{|c|}{$P$-value } \\
\hline Intake, $\mathrm{kg} / \mathrm{d}$ & 23.1 & 25.5 & 22.4 & 25.6 & 1.3 & 0.83 & 0.04 & 0.77 \\
\hline Apparent total-tract digestion, $\%$ & 69.4 & 70.7 & 67.7 & 68.6 & 1.2 & 0.14 & 0.37 & 0.88 \\
\hline \multicolumn{9}{|l|}{$\mathrm{OM}$} \\
\hline \multicolumn{9}{|l|}{ Starch } \\
\hline Intake, kg/d & 5.14 & 5.42 & 4.67 & 5.62 & 0.33 & 0.69 & 0.07 & 0.32 \\
\hline Apparent ruminal digestion, $\%$ & 91.6 & 86.2 & 86.7 & 87.8 & 1.8 & 0.38 & 0.24 & 0.10 \\
\hline Apparent total-tract digestion, $\%$ & 98.1 & 97.5 & 96.4 & 97.5 & 0.4 & 0.04 & 0.49 & 0.06 \\
\hline
\end{tabular}

${ }^{1}$ LFDCS $=$ low-fiber digestibility corn silage; HFDCS = high-fiber digestibility corn silage.

${ }^{2}$ DMI restricted to $90 \%$ of ad libitum DMI.

et al. (2010a) reported iNDF kp ranged from 2.66 to $2.87 \% / \mathrm{h}$ for corn silage diets, the values for iNDF $\mathrm{kp}$ presented in their meta-analysis are lower than the values observed in our trial and other studies reported previously. This could be explained by the lower intake level (approximately $16.6 \mathrm{~kg} / \mathrm{d}$ ) and combined data from dairy and beef cattle studies in the meta-analysis.

\section{Nutrient Digestibility}

Total-tract digestibility of DM, OM, and starch is presented in Table 7. No interactions between main treatment effects (silage $\times$ intake) were observed for any measurement of DM or OM digestibility (Table 7). In addition, digestibility of DM and OM were not affected by corn silage type. This is consistent with other studies with lactating cows comparing BMR and conventional corn silage (Oba and Allen, 2000b; Greenfield et al., 2001; Tine et al., 2001; Qiu et al., 2003; Barlow et al., 2012), although a tendency ( $P=$ 0.07 ) for increases in percentage of apparent total-tract OM digestion for LFDCS diets was noted. Tine et al. (2001) reported that apparent digestibilities of OM and DM were generally unaffected by level of intake for BMR corn silage diets. Oba and Allen (2000b) observed that ruminal OM digestibility was reduced and postruminal digestion was increased for BMR as compared with conventional corn silage diets in a study with dairy cows in early lactation (70 DIM), although no difference was observed for total-tract digestibility. Greenfield et al. (2001) reported the opposite treatment effects, with higher ruminal digestibility of DM and a tendency for increased ruminal OM digestion for BMR diets in a study with late lactation (221 DIM) cows. In spite of the difference observed in some studies for ruminal digestibilities of $\mathrm{OM}$ and $\mathrm{DM}$ when BMR and conventional corn silages were compared, postruminal digestion of these nutrients were entirely compensated with no differences of total-tract OM digestion.

Total-tract starch digestibility ranged from 96.4 to $98.1 \%$ of starch across treatments, with a slightly higher value for the restricted LFDCS diet (Table 7). Barlow et al. (2012), Tine et al. (2001), Taylor and Allen (2005), Greenfield et al. (2001), and Weiss and Wyatt (2006) found no differences in total-tract starch digestibility when comparing diets with conventional versus BMR corn silages. Total-tract starch digestibility was higher for cows fed conventional than BMR corn silage when different levels of NDF in the diet were tested by Oba and Allen (2000b). We observed a tendency $(P=0.06)$ for an interaction between silage and intake for starch total-tract digestion (Table 7).

Intake of NDF, pdNDF, and iNDF were affected by the intake level (Table 8). Contrary to our hypothesis, no interaction of main treatment effects (silage $\times$ intake) was observed for digestibility of NDF and pdNDF (Table 8). As noted in Table 6, ruminal passage of NDF did not differ due to silage or level of intake. Ruminal NDF digestibilities were similar for corn silage source and intake level; numerically, restricted and ad libitum HFDCS (43.1 and $41.5 \%$, respectively) were greater than restricted and ad libitum LFDCS diets (35.1 and 40.5\%, respectively; Table 8). Similar patterns were observed for total-tract NDF digestion; restricted and ad libitum HFDCS (51.2 and 49.4\%, respectively) were numerically greater than restricted and ad libitum LFDCS diets (49.9 and $47.5 \%$, respectively). We expected a slower passage rate of NDF for restricted diets and, consequently, an increase in digestibility; however, no differences in passage rate for NDF (Table 6) were observed. This shows that the restriction intake of $90 \%$ of ad libitum intake was not enough to affect rumen pools of NDF, iNDF, or turnover rate of NDF (Table 6), although this moderate restriction of DMI was enough to affect milk yield, as shown 
in Table 4. Taylor and Allen (2005) and Oba and Allen (2000b) also did not observe changes in ruminal NDF and pdNDF digestibility when BMR was compared with conventional corn silage. Greenfield et al. (2001) reported differences for ruminal NDF digestion when BMR diet was 15 units higher in NDF digestibility compared with a conventional corn silage diet. Total-tract NDF digestibility for BMR compared with control silages diets have shown different responses among studies; for instance, Tine et al. (2001), Oba and Allen (2005a), and Barlow et al. (2012) reported positive responses in milk yield and NDF digestibility by feeding BMR. Conversely, no differences in NDF digestibilities were observed by Greenfield et al. (2001) and Oba and Allen (2000b) when BMR was fed compared with conventional corn silage.

We observed that iNDF intake $(\mathrm{kg} / \mathrm{d})$ was higher $(P$ $=0.03$ ) for diets with LFDCS (Table 8), also ruminal passage rate for pdNDF tended $(P=0.09)$ to be faster for LFDCS than HFDCS diets. However, pdNDF digestion rate was similar among diets resulting in similar ruminal digestibilities of pdNDF (Table 8). The apparent digestibility of pdNDF was higher in diets containing LFDCS than HFDCS, because LFDCS showed a faster kd for pdNDF compared with HFDCS diets (Table 6).

Although in vitro NDF digestibility was 1.6 and 9.8 units higher for HFDCS than LFDCS at 30 and $48 \mathrm{~h}$, respectively, HFDCS diets did not increase ruminal or postruminal fiber digestion. It also did not affect rates of iNDF passage or pdNDF digestion in vivo measurements. Similar results has been shown in studies using BMR (Oba and Allen, 2000b; Greenfield et al., 2001; Ebling and Kung, 2004; Taylor and Allen, 2005).

\section{In Vitro Versus In Vivo}

The input variables (pdNDF intake, $\mathrm{kd}$, and $\mathrm{kp}$ ) and output (ruminal, hindgut, and total-tract NDF digestion) values predicted from in vitro model were compared with what was observed in vivo (Table 9). The pdNDF intake predicted from in vitro model was similar to pdNDF intake observed in vivo. In addition, no differences were observed for pdNDF $\mathrm{kd}$ and $\mathrm{kp}$ between methods (Table 9). The fixed value $2.67 \%$ /h for pdNDF kp used in the TTNDFD model was similar to what was measured in vivo and is in the range observed in other in vivo trials (Oba and Allen, 2000b; Taylor and Allen, 2005). The pdNDF kd predicted in vitro was similar to what was observed in vivo.

Predicted rumen pdNDF $\mathrm{kd}$ and TTNDFD of treatment diets for in vitro method are presented in Table 3 , and for in vivo method are presented in Tables 6 and 8 . The in vitro method predicted TTNDFD of $50.2 \%$ for HFDCS and $42.9 \%$ LFDCS as percentage of total NDF in the diets (Table 3), whereas in vivo measurements of TTNDFD for HFDCS and LFDCS diets averaged 50.3 and $48.6 \%$ of total NDF in the diets, respectively (Table 8). The in vitro TTNDFD assay predicted total-tract NDF digestibility of HFDCS diets similar to digestibility observed in vivo, but for LFDCS diets this test underestimated the digestibility compared with in vivo. The hindgut NDF digestibility for HFDCS was 11.8 and $11.1 \%$ as percentage of total NDF intake for ad libitum and restricted diets, respectively. However, the hindgut NDF digestibility for LFCSD was $4.6 \%$ for restricted and $10.4 \%$ for ad libitum diets. The lower value for hindgut NDF digestibility for restricted LFDCS could explain why the in vitro model underestimated the TTNDFD for LFDCS diets compared with in vivo, as the in vitro model assumes that $10 \%$ of NDF digestion occurs in the hindgut. When the in vitro and in vivo models were compared without intake effect (ad libitum and restricted), considering only diet effect of silage fiber digestibility (HFDCS and

Table 8. Effects of corn silage type and intake level on digestion of NDF

\begin{tabular}{|c|c|c|c|c|c|c|c|c|}
\hline \multirow[b]{2}{*}{ Item } & \multicolumn{2}{|c|}{$\operatorname{LFDCS}^{1}$} & \multicolumn{2}{|c|}{$\mathrm{HFDCS}^{1}$} & \multirow[b]{2}{*}{ SEM } & \multicolumn{3}{|c|}{$P$-value } \\
\hline & Restricted $^{2}$ & ad libitum & restricted & ad libitum & & Silage & Intake & $\begin{array}{c}\text { Silage } \\
\times \text { intake }\end{array}$ \\
\hline Intake, $\mathrm{kg} / \mathrm{d}$ & 6.04 & 6.99 & 6.03 & 7.27 & 0.34 & 0.72 & $<0.01$ & 0.72 \\
\hline Apparent ruminal digestion, $\%$ of NDF & 35.1 & 40.5 & 43.1 & 41.5 & 3.5 & 0.24 & 0.55 & 0.36 \\
\hline Passage to omasum, kg/d & 3.92 & 4.56 & 3.64 & 3.95 & 0.36 & 0.21 & 0.15 & 0.63 \\
\hline Intake, $\mathrm{kg} / \mathrm{d}$ & 3.88 & 4.57 & 4.17 & 5.14 & 0.23 & 0.10 & $<0.01$ & 0.58 \\
\hline Apparent ruminal digestion, $\%$ of pdNDF & 61.0 & 58.9 & 58.0 & 63.4 & 4.5 & 0.95 & 0.64 & 0.52 \\
\hline Passage to omasum, $\mathrm{kg} / \mathrm{d}$ & 1.52 & 1.89 & 1.75 & 1.88 & 0.25 & 0.64 & 0.27 & 0.60 \\
\hline Apparent total-tract digestion, $\%$ of pdNDF & 75.0 & 78.7 & 71.2 & 69.1 & 3.2 & 0.04 & 0.78 & 0.35 \\
\hline $\mathrm{iNDF}^{3}$ intake, $\mathrm{kg} / \mathrm{d}$ & 2.16 & 2.42 & 1.86 & 2.13 & 0.12 & 0.03 & 0.04 & 0.97 \\
\hline
\end{tabular}

${ }^{1}$ LFDCS $=$ low-fiber digestibility corn silage; HFDCS = high-fiber digestibility corn silage.

${ }^{2}$ DMI restricted to $90 \%$ of ad libitum DMI.

${ }^{3} \mathrm{iNDF}=$ indigestible NDF determined by in situ incubation for $288 \mathrm{~h}$. 
Table 9. Comparison of rumen and total-tract NDF digestion of diets predicted from TTNDFD model and observed in vivo

\begin{tabular}{|c|c|c|c|c|}
\hline \multirow[b]{2}{*}{ Item } & \multicolumn{2}{|c|}{ Method } & \multirow[b]{2}{*}{ SEM } & \multirow{2}{*}{$\frac{P \text {-value }}{\text { Method }}$} \\
\hline & Predicted & In vivo & & \\
\hline \multicolumn{5}{|l|}{ Input } \\
\hline pdNDF. ${ }^{2} \mathrm{~kg} / \mathrm{d}$ & 4.74 & 4.44 & 0.20 & 0.20 \\
\hline pdNDF kd, ${ }^{3} \% / \mathrm{h}$ & 4.11 & 4.27 & 0.46 & 0.72 \\
\hline pdNDF $\mathrm{kp},{ }^{4} \% / \mathrm{h}$ & 2.67 & 2.79 & 0.35 & 0.56 \\
\hline \multicolumn{5}{|l|}{ Output } \\
\hline $\mathrm{NDF}$ digested in rumen, $\mathrm{kg}$ & 2.73 & 2.63 & 0.22 & 0.64 \\
\hline NDF digested in hindgut, $\mathrm{kg}$ & 0.36 & 0.64 & 0.19 & 0.05 \\
\hline NDF digestibility in total-tract, $\mathrm{kg}$ & 3.09 & 3.27 & 0.22 & 0.42 \\
\hline Total-tract NDF digestibility, $\%$ of total NDF & 46.4 & 49.5 & 2.07 & 0.13 \\
\hline
\end{tabular}

LFDCS), no differences $(P=0.13)$ were observed between methods (Table 9 ). The in vitro model predicted the TTNDFD of $46.4 \pm 4.4 \%$ compared with $49.5 \pm$ $6.1 \%$ for in vivo method. These values suggest that the in vitro TTNDFD model could be used to predicted NDF digestibility for a high-producing dairy cow. Colombini et al. (2012) compared total-tract NDF digestion measured from fecal collection to total-tract NDF digestion predicted from an in vitro assay according to CNCPS model version 6.1 (Tylutki et al., 2008). The in vitro prediction values $(37.8 \%)$ for corn silages diets were lower than in vivo measurements $(51.5 \%)$ using the same diets. The authors suggested that the underestimation of NDF digestion by the in vitro assay could be explained by an overestimation of the kp. Krizsan et al. (2010a) suggests that the kp estimates derived from rumen evacuation data were lower than those predicted from the CNCPS model. The CNCPS model uses a regression that predicts passage of labeled particles from the rumen, and assumes that particle passage rates are similar to NDF passage rate. Colombini et al. (2012) also noted that the CNPCS model calculated the iNDF fraction as $2.4 \times$ lignin for corn silage. In our laboratory, we have observed that the pool of iNDF is smaller when calculated as $2.4 \times$ lignin than when determined by long incubation time either 240 (in vitro) or 288 $\mathrm{h}$ (in situ) incubations. The underestimation of iNDF pool can result in an underestimation of pdNDF kd and vice versa (Colombini et al., 2012).

\section{CONCLUSIONS}

The NDF digestibility coefficients predicted by the in vitro TTNDFD method were similar to the in vivo values. The digestibility coefficients suggested that a restriction on intake of $90 \%$ of ad libitum would not change the rate of passage and digestion among corn silages that differ in iNDF composition. Despite of the greater pdNDF available in HFDCS silage, it did not improve fiber digestibility compared with LFDCS silage when was fed to dairy cows. The in vitro estimates of pdNDF intake and rate of digestion of pdNDF were similar to what was observed in vivo, and when applied to relatively simple model was a good predictor of in vivo fiber digestion. The TTNDFD model can be a valuable tool for optimizing forage utilization and compare the fiber digestibility of TMR fed to dairy cattle.

\section{ACKNOWLEDGMENTS}

Appreciation is extended to USDA Hatch Multi-State Research Formula Fund \#WIS01635 and \#WIS01546 for funding this project. The authors thank Mike Peters and Valerie Schutzkus and the staff at the University of Wisconsin Dairy Cattle Center (Madison) for animal care and trial management; Kathryn Ruh (dairy science undergraduate at UW-Madison) for her dedication and help during the animal trials and laboratory work; University of Wisconsin Dairy Science graduate students for their help during the rumen evacuation sampling; and Peter Crump of the CALS Computer Consulting Laboratory (University of Wisconsin, Madison) for assistance with statistical analysis of the data.

\section{REFERENCES}

Ahvenjärvi, S., A. Vanhatalo, P. Huhtanen, and T. Varvikko. 2000 Determination of reticulo-rumen and whole-stomach digestion in lactating cows by omasal canal or duodenal sampling. Br. J. Nutr. 83:67-77.

AOAC International. 2006. Official Methods of Analysis. 18th ed. AOAC International, Arlington, VA.

Bach Knudsen, K. E. 1997. Carbohydrate and lignin contents of plant materials used in animal feeding. Anim. Feed Sci. Technol. 67:319-338.

Bal, M. A., R. D. Shaver, H. Al-Jobeile, J. G. Coors, and J. G. Lauer. 2000. Corn silage hybrid effect on intake, digestion, and milk production by dairy cows. J. Dairy Sci. 83:2849-2858. 
Ballard, C. S., E. D. Thomas, E. S. Tsang, P. Mandebvu, C. J. Sniffen, M. I. Endres, and M. P. Carter. 2001. Effect of corn silage hybrid on dry matter yield, nutrient composition, in vitro digestion, intake by dairy heifers, and milk production by dairy cows. J. Dairy Sci. 84:442-452.

Barlow, J. S., J. K. Bernard, and N. A. Mullis. 2012. Production response to corn silage produced from normal, brown midrib, or waxy corn hybrids. J. Dairy Sci. 95:4550-4555.

Block, E., L. D. Muller, L. C. Griel, and D. L. Garwood. 1981. Brown midrib-3 corn silage and heat extruded soybeans for early lactating dairy cows. J. Dairy Sci. 64:813-825.

Colombini, S., G. Galassi, G. M. Crovetto, and L. Rapetti. 2012. Milk production, nitrogen balance, and fiber digestibility prediction of corn, whole plant grain sorghum, and forage sorghum silages in the dairy cow. J. Dairy Sci. 95:4457-4467.

Combs, D. K. 2013.TTNDFD: A new approach to evaluate forages. Pages 113-125 in Proc. 2013 Cornell Nutr. Conf. Dept. Anim. Sci., Cornell Univ., Ithaca, NY.

Eastridge, M. L. 1999. Brown midrib corn silage. Pages 179-190 in Proc. Tri-State Dairy Nutr. Conf. The Ohio State University, Columbus.

Ebling, T. L., and L. Kung Jr.. 2004. A comparison of processed conventional corn silage to unprocessed and processed brown midrib corn silage on intake, digestion, and milk production by dairy cows. J. Dairy Sci. 87:2519-2526.

Ellis, W. C., J. H. Matis, T. M. Hill, and M. R. Murphy. 1994. Methodology for estimating digestion and passage kinetics of forages. Pages $682-756$ in Forage Quality, Evaluation and Utilization. G. C. Fahey Jr., M. Collins, D. R. Mertens, and L. E. Moser, ed. Am. Soc. Agron., Crop Sci. Soc. Am., Soil Sci. Soc. Am., Madison, WI.

France, J., and R. C. Siddons. 1986. Determination of digesta flow by continuous marker infusion. J. Theor. Biol. 121:105-120.

Gehman, A. M., P. J. Kononoff, C. R. Mullins, and B. N. Janicek. 2008. Evaluation of nitrogen utilization and the effects of monensin in dairy cows fed brown midrib corn silage. J. Dairy Sci. 91:288-300.

Goeser, J. P., and D. K. Combs. 2009. An alternative method to assess 24-h ruminal in vitro neutral detergent fiber digestibility. J. Dairy Sci. $92: 3833-3841$.

Greenfield, T. L., R. L. Baldwin, R. A. Erdman, and K. R. McLeod. 2001. Ruminal fermentation and intestinal flow of nutrients by lactating cows consuming brown midrib corn silages. J. Dairy Sci. $84: 2469-2477$.

Huhtanen, P., U. Asikainen, M. Arkkila, and S. Jaakkola. 2007. Cell wall digestion and passage kinetics estimated by marker and in situ methods or by rumen evacuations in cattle fed hay 2 or 18 times daily. Anim. Feed Sci. Technol. 133:206-227.

Huhtanen, P., P. G. Brotz, and L. D. Satter. 1997. Omasal sampling technique for assessing fermentative digestion in the forestomach of dairy cows. J. Anim. Sci. 75:1380-1392.

Huhtanen, P., K. Kaustell, and S. Jaakkola. 1994. The use of internal markers to predict total digestibility and duodenal flow of nutrients in cattle given six different diets. Anim. Feed Sci. Technol. 48:211-227.

Kendall, C., C. Leonardi, P. C. Hoffman, and D. K. Combs. 2009. Intake and milk production of cows fed diets that differed in dietary neutral detergent fiber and neutral detergent fiber digestibility. J. Dairy Sci. 92:313-323.

Krizsan, S. J., and P. Huhtanen. 2013. Effect of diet composition and incubation time on feed indigestible neutral detergent fiber concentration in dairy cows. J. Dairy Sci. 96:1715-1726.

Krizsan, S. J., S. Ahvenjarvi, and P. Huhtanen. 2010a. A meta-analysis of passage rate estimated by rumen evacuation with cattle and evaluation of passage rate prediction models. J. Dairy Sci. 93:5890-5901.

Krizsan, S. J., S. Ahvenjarvi, H. Volden, and G. A. Broderick. 2010b. Estimation of rumen outflow in dairy cows fed grass silage-based diets by use of reticular sampling as an alternative to sampling from the omasal canal. J. Dairy Sci. 93:1138-1147.

Kung, L., Jr., B. M. Moulder, C. M. Mulrooney, R. S. Teller, and R. J. Schmidt. 2008. The effect of silage cutting height on the nutritive value of a normal corn silage hybrid compared with brown midrib corn silage fed to lactating cows. J. Dairy Sci. 91:1451-1457.

Lund, P., M. R. Weisbjerg, and T. Hvelplund. 2007. Digestible NDF is selectively retained in the rumen of dairy cows compared to indigestible NDF. Anim. Feed Sci. Technol. 134:1-17.

Mertens, D. R. 1993. Kinetics of cell wall digestion and passage in ruminants. Pages 535-570 in Forage Cell Wall Structure and Digestibility. H. G. Jung, D. R. Buxton, R. D. Hatfield, and J. Ralph, ed. American Society of Agronomy, Madison, WI.

Mertens, D. R. 2002. Physical and chemical characteristics of fiber affecting dairy cow performance. Pages 124-144 in Proc. 2002 Cornell Nutr. Conf. Dept. Anim. Sci., Cornell Univ., Ithaca, NY.

Mouriño, F., R. Akkarawongsa, and P. J. Weimer. 2001. Initial pH as a determinant of cellulose digestion rate by mixed ruminal microorganisms in vitro. J. Dairy Sci. 84:848-859.

NorFor. 2011. NorFor: The Nordic Feed Evaluation System. H. Volden ed. EAAP publication no. 130. Wageningen Acad Publ., Wageningen, the Netherlands.

NRC. 2001. Nutrient Requirements of Dairy Cattle. 7th rev. ed. Natl. Acad. Sci., Washington, DC.

Oba, M., and M. S. Allen. 2000a. Effects of brown midrib 3 mutation in corn silage on productivity of dairy cows fed two concentrations of dietary neutral detergent fiber: 1 . Feeding behavior and nutrient utilization. J. Dairy Sci. 83:1333-1341.

Oba, M., and M. S. Allen. 2000b. Effects of brown midrib 3 mutation in corn silage on productivity of dairy cows fed two concentrations of dietary neutral detergent fiber: 3 . Digestibility and microbial efficiency. J. Dairy Sci. 83:1350-1358.

Qiu, X., M. L. Eastridge, and Z. Wang. 2003. Effects of corn silage hybrid and dietary concentration of forage NDF on digestibility and performance by dairy cows. J. Dairy Sci. 86:3667-3674.

Reynal, S. M., and G. A. Broderick. 2005. Effect of dietary level of rumen-degraded protein on production and nitrogen metabolism in lactating dairy cows. J. Dairy Sci. 88:4045-4064.

SAS Institute. 2009. SAS/STAT 9.3 User's Guide. Version 9.3 ed. SAS Institute Inc., Cary, NC.

Supelco. 1998. Analyzing fatty acids by packed column gas chromatography. Technical Bulletin \#856B. Supelco Inc., Bellefonte, PA.

Taylor, C. C., and M. S. Allen. 2005. Corn grain endosperm type and brown midrib 3 corn silage: Site of digestion and ruminal digestion kinetics in lactating cows. J. Dairy Sci. 88:1413-1424.

Tine, M. A., K. R. McLeod, R. A. Erdman, and R. L. Baldwin VI. 2001. Effects of brown midrib corn silage on the energy balance of dairy cattle. J. Dairy Sci. 84:885-895.

Tylutki, T. P., D. G. Fox, V. M. Durbal, L. O. Tedeschi, J. B. Russell, M. E. Van Amburgh, T. R. Overton, L. E. Chase, and A. N. Pell. 2008. Cornell Net Carbohydrate and Protein System: A model for precision feeding of dairy cattle. Anim. Feed Sci. Technol. 143:174-202

Udén, P., P. E. Colucci, and P. J. Van Soest. 1980. Investigation of chromium, cerium and cobalt as markers in digesta: Rate of passage studies. J. Sci. Food Agric. 31:625-632.

Van Soest, P. J., J. B. Robertson, and B. A. Lewis. 1991. Methods of dietary fiber, neutral detergent fiber and non-polysaccharides in relation to animal nutrition. J. Dairy Sci. 74:3583-3597.

Volden, H. ed. 2011. NorFor - The Nordic Feed Evaluation System. EAAP publication no.130. Wageningen Acad. Publ., Wageningen, The Netherlands.

Waldo, D. R., L. W. Smith, and E. L. Cox. 1972. Model of cellulose disappearance from the rumen. J. Dairy Sci. 55:125-129.

Weiss, W. P., and D. J. Wyatt. 2006. Effect of corn silage hybrid and metabolizable protein supply on nitrogen metabolism of lactating dairy cows. J. Dairy Sci. 89:1644-1653. 